\title{
A spatial model of forest and land fire vulnerability level in the Dairi District, North Sumatra, Indonesia
}

\author{
ACHMAD SIDDIK THOHA ${ }^{\vee}$, HESTY TRIANI \\ Faculty of Forestry, Universitas Sumatera Utara. Jl. Tri Dharma Ujung No. 1, Kampus USU Padang Bulan, Medan 20155, North Sumatra, Indonesia \\ Tel./fax.: +62-61-8201920 •email: a.siddik@usu.ac.id.
}

Manuscript received: 7 July 2021. Revision accepted: 19 July 2021.

\begin{abstract}
Thoha AS, Triani H. 2021. A spatial model of forest and land fire vulnerability level in the Dairi District, North Sumatra, Indonesia. Biodiversitas 22: 3319-3326. Fires often occur every dry season and have a significant impact on ecosystems and human activities. One of the important roles in reducing the risk of forest and land fires is the availability of updated vulnerability level maps in all vulnerable areas. The objective of this study was to determine the relationship between the driving factors for forest and land fires and hotspots and to obtain a spatial model of the distribution of vulnerability to forest and land fires in the Dairi District of North Sumatra Province. This study uses a composite mapping analysis method to obtain a spatial model and the distribution of vulnerable areas to forest and land fires. Six variables in the form of maps were used in building the model, including land cover, population density, distance from the road, distance from the river, and distance from the settlement. This study showed that the most important variable for vulnerability level model of forest and land fires was the distance from the settlement. This study also found that open land, the farthest distance to the road, the farthest distance to the river, the farthest distance to the settlement, and the dense st population were the driving factors for increased fire activity. The spatial model of the vulnerability level to forest and land fires in Dairi District was $\mathrm{Y}$ $=0.022 \mathrm{X}_{1}+0.214 \mathrm{X}_{2}+0.113 \mathrm{X}_{3}+0.482 \mathrm{X}_{4}+0.169 \mathrm{X}_{5}$. Land cover having high-very high vulnerability level belonged to open land dominated by grass. The largest areas with a high-very high forest fire vulnerability level in Dairi District were spread over Tanah Pinem Sub-district.
\end{abstract}

Keywords: Composite Mapping Analysis, forest and land fires, vulnerability level maps

\section{INTRODUCTION}

Massive fires in many areas in Indonesia during 2015 produced 700-800 million tonnes of $\mathrm{CO}_{2}$ (Kiely et al. 2019; Huijnen et al. 2016), causing a loss of IDR $221 \mathrm{~T}$ (World Bank 2015), and affecting 69 million people (Crippa et al. 2016). The air pollution exposure was estimated to cause 11,880 deaths in the short term and 100,300 premature deaths in the long term (Koplitz et al. 2016). Peatland areas experienced rapid land cover change and frequent fires in Central and South Sumatra and Southwest Kalimantan contributed most to regional air quality problems (Reddington et al. 2014)

North Sumatra Province is one of the areas that are more vulnerable to disasters, including forest and land fires. The steep topography and the wide area of critical and abandoned lands that dominate several regencies in North Sumatra are natural conditions that hold the potential for forest and land fire hazards. In general, the areas with a high vulnerability level to the forest and land fires in North Sumatra are peatlands and steep-sloped lands covered with shrubs and grasslands (Thoha and Ahmad 2018). Critical and abandoned land in the form of shrubs and grasslands is the trigger for the initial fires in the forest and land fires in Kapuas District (Thoha et al., 2014; Thoha et al. 2017) and North Sumatra Province (Thoha and Ahmad 2018).

In the long term, the impact of fire will result in further disasters, such as loss of biodiversity, global warming, and desertification (Goldammer et al. 2006). Secondary disasters after forest and land fires will also occur if the burned lands are left without restoration. Land and forest damaged by forest and land fires have the potential danger of further disasters that will threaten lives and losses in various aspects in the future.

In the past, North Labuhanbatu District has often faced forest and land fires. According to BNPB (2016), one of the areas with a high frequency of disasters in North Sumatra is North Labuhanbatu District. This has also been studied by Thoha and Ahmad (2018) where there are areas with a high and very high vulnerability level of forest and land fire, analyzed from the history of hotspots ten years ago. Land conversion from forest to other land cover resulting in loss of area function in disaster protection services has not been widely studied. Development planning often neglects the aspect of land capacity in carrying out its ecological functions.

The factors causing forest and land fires are based on several studies related to climate and human activities. Ceccato et al. (2010) found that there was a relationship between the rainfall anomaly and hotspots indicating fires in Central Kalimantan. Rainfall anomaly during the dry season in June-October is a critical time of fire activity. A study by Jaya et al. (2007) revealed that human activity factors contribute the most to fire risk as well as changes in land cover. Thoha et al. (2017) also found that land cover hotspots made a major contribution to the fire risk model in Kapuas District, Central Kalimantan Province. 
Therefore, a proper understanding is required of how land resources are managed to minimize fires and their related environmental impacts. One of the efforts to minimize the risk of forest and land fires is the creation of vulnerability level maps in a number of vulnerable areas. Vulnerability maps have a very important role in controlling forest and land fires. The vulnerability map contains the distribution of areas that have a high sensitivity for forest and land fires. The vulnerability level map also finds the main driving factors of forest and land fires. The forest and land fire vulnerability map can also predict activities that could pose a risk of forest and land fires in particular areas in the future. The objective of this study was to obtain the relationship between the driving factors for forest and land fires, hotspots and to obtain a spatial model of the distribution of forest and land fire vulnerability levels in Dairi District, North Sumatra Province.

\section{MATERIALS AND METHODS}

\section{Study area}

The study was conducted in February-July 2019 in Dairi District, North Sumatra Province, Indonesia as it is one of the vulnerable areas to fires. Field data collection and interviews were conducted in seven villages belonging to Tanah Pinem and Silahisabungan, which are two subdistricts in Dairi District.

\section{Procedure}

Hotspot data from Terra/Aqua Satellite using the MODIS (Moderate-resolution Imaging Spectroradiometer) sensor in 2016 were obtained from the Fire Information for Resource Management System (FIRMS) which can be accessed for free at https://firms.modaps.eosdis.nasa.gov/download. District and district administrative boundary maps were obtained from the Development Planning Agency at the SubNational Level of Dairi District. Land cover maps, river network maps, road network maps, and settlement maps were obtained from the Geospatial Information Agency via www.tanahair.indonesia.go.id. The 2015 population density map was obtained via Open Demographic Data and Research which can be accessed at the https:www.worldpop.org. Hotspots were also used as the basis for determining the location of the ground check. The tools used in this study were personal computers, ArcGIS 10.5 software, and Global Positioning System (GPS) navigation Type Garmin 76s with approximately $15 \mathrm{~m}$ accuracies.

The mapping of areas vulnerable to forest and land fires in Dairi District was carried out by collecting hotspot distribution data. The ArcGis 10.5 software was used to process the data. Data processing using ArcGIS 10.5 including spatial join, intersect, attribute editing, calculates geometry, and files a calculator to score each variable. Spatial calculator was used to determine composite score of fire vulnerability level and visualize spatial equation to a map. Vulnerability classes are divided into five class using reclassify feature in ArcMap 10.5. to arrange fire vulnerability level map. Hotspot verification was carried out by comparing the accuracy of the hotspot location detected from the Terra/Aqua satellite with the results of field truthing. The field data collection included data on the geographic position of the fire location, land cover, and community activities.

The method of determining the forest and land fire vulnerability level used Composite Mapping Analysis (CMA) following modifications upon method developed by Jaya et al. (2007), Thoha et al. (2017), and Thoha and Ahmad (2018). The steps for determining the level of fire vulnerability level were classifying the building blocks of the model, calculating the score per variable, determining the estimated score, determining the scale score, weighting the variables, making mathematical equations and finally making a map of the level of fire vulnerability.

\section{Data analysis}

Classification

Each factor used in the construction of the model was divided into several classes as listed in Table 1.

\section{Determination of weight}

The weight determination of the spatial model was carried out empirically by using the Composite Mapping Analysis (CMA) method. The relationship between the number of hotspots per $\mathrm{km}^{2}$ (hotspot density) and the constituent variables of forest and land fire vulnerability level was analyzed to reduce the score of each factor. Variables with a relatively higher correlation than other factors were selected and used to construct a linear regression model. Each weight was taken as the proportion of individual correlation coefficient from the linear regression to the total of all regression coefficients (Thoha et al. 2017). The steps for determining the weight of the constituent variables for forest and land fire vulnerability level in Dairi District were as follows:

Table 1. Classification of the factors used in the construction of the model

\begin{tabular}{lll}
\hline Variable & Factor & Class \\
\hline X1 & Land Cover/Use & Water Body \\
& & Shrub \\
& Secondary Dryland Forest \\
& & Plantation Forest \\
& Settlement \\
& & Dryland Farming \\
& & Mixed Dry Land Farming \\
& & Swamp \\
& & Paddy Field \\
& & Open Land \\
& & Divided into 5 classes: $1=$ \\
X2 & Population density & $0.1-0.3$ people/km ${ }^{2}, 2=0.3-$ \\
& & $0.6,3=0.6-0.9,4=0.9-1.5$, \\
& & $5=1.5-38.9$ \\
& & Buffer at intervals of $500 \mathrm{~m}$ \\
X3 & Distance from the Road & Buffer at intervals of $500 \mathrm{~m}$ \\
X4 & Distance from the River & Buffer at intervals of $500 \mathrm{~m}$ \\
X5 & Distance from the & \\
& Settlement & \\
\hline
\end{tabular}


Score score calculation

The score of each sub-factor can be calculated using formulas (1) and (2)

$$
\begin{aligned}
& X i=\left[\frac{0_{i}}{\varepsilon_{i}}\right] x \frac{100}{\Sigma\left(\frac{0 i}{V_{i}}\right)} \\
& E i=\left[\frac{T X F}{100}\right]
\end{aligned}
$$

Where:

$\mathrm{X}_{\mathrm{i}}=$ class (sub-factor) score on each factor

$\mathrm{O}_{\mathrm{i}}=$ the number of hotspots in each class (observed hotspots)

$\mathrm{E}_{\mathrm{i}}=$ number of hotspots expected in each class (expected hotspot)

$\mathrm{T}=$ the total number of hotspot

$\mathrm{F}=$ percentage of area in each class

\section{Estimated score calculation}

Based on the trend line pattern, the relationship between the actual score of each factor and the hotspot density (number of hotspots $/ \mathrm{km}^{2}$ ), the estimated score according to the pattern (regression equation) which has a relatively higher coefficient of determination was calculated.

\section{Calculation of the scale score}

To obtain the same standard score among all the factors to be used in making the model, the score was calculated again to obtain a scale score using the formula by Jaya et al. (2007) as shown below (equation 3):

$$
\text { Score } R_{\text {out }}=\left[\left(\frac{\text { Score }_{\text {input }}-S_{\text {Score }} E_{\min }}{\text { Score }_{\max }-\text { Score }_{\min }}\right) \times\left(\text { Score } R_{\max }-\text { Score }_{\min }\right)\right]+\text { Score } R_{\min }
$$

\section{Where:}

Score $\mathrm{R}_{\text {out }}=$ rescaling result score

Score $\mathrm{E}_{\text {input }}=$ the estimated score of the input

Score $\mathrm{E}_{\min }=$ the minimum estimated score

Score $\mathrm{E}_{\max }=$ the maximum estimated score

Score $\mathrm{R}_{\max }=$ the highest score of rescaling results

Score $\mathrm{R}_{\min }=$ the lowest score of rescaling results

\section{Mathematical equations}

The composite score was determined by the CMA method, with the weight derived from the coefficient of each composite constituent factor. Based on the composite score, a mathematical equation that stated the relationship between the number of hotspots per $\mathrm{km}^{2}$ and the composite score of the constituent factors was formulated. The composite score is determined by weight derived from each coefficient of the factors of the composite constituent. Based on the scores and weights of each variable, arranged a mathematical equation as follows (Equation 4):

$$
y=w 1 x 1+w 2 x 2 \ldots+w i x i
$$

Where:

$$
\begin{aligned}
& \mathrm{y}=\text { Composite score model } \\
& \mathrm{Wi}=\text { Variable weight } \ldots-\mathrm{i} \\
& \mathrm{xi}=\text { Variable rescaled score } \ldots-\mathrm{i}
\end{aligned}
$$

Making a map of fire vulnerability classes

The fire vulnerability class was grouped into five classes with a natural break classification based on the pixel size used and the radius between the hotspots.

\section{The construction of the spatial model of the forest and land fire vulnerability level}

In spatial modeling of the vulnerability level to forest and land fires, two activities were carried out, including; (i) making a map of the forest and land fire vulnerability level resulting from the best equation, then seeing the total area of fire vulnerability level from various perspectives, and (ii) making a distribution of risk classes of forest and land fire based on administrative areas and finding factors that have an important role in estimating hotspot density.

\section{RESULTS AND DISCUSSION}

\section{Hotspot distribution}

In general, the hotspots were densely distributed in the western area of the Dairi District compared to the eastern area. Tanah Pinem Sub-district is in western part of the Dairi District. Tanah Pinem Sub-district is an area that is considered advanced in its agricultural sector. In 2016, the productivity of corn and cassava reached 29,669 tons and 430 tons, respectively. For the paddy field in Tanah Pinem Sub-district, the harvest area for 2016 reached 470,000 ha (Statistics Indonesia of Dairi District 2018). The survey results showed that the habit of burning land for agricultural activities was still the easiest alternative for farmers. Various activities that were often carried out by communities around the forest used fire, which could not be separated from their connection with livelihoods or additional activities.

Temporally, the hotspots were detected every mid-year, including in June and July, where the number of hotspots increased and reached its peak. Meanwhile, from January to May and August to December, the number of hotspots decreased or even did not exist at the beginning and end of the year from January to May and August to December.

The highest number of hotspots were identified in land cover types of dryland farming, shrubs, secondary dryland forest and open land. On the front of agricultural sector, Dairi District is a fairly large producer of agricultural crops. However, the community's habit of opening and clearing land by burning was still practiced by the community.

The eastern area of the Dairi District includes the Silahisabungan Sub-district. Based on Figure 1, the number of hotspots was relatively low compared to that of the western region. The characteristics of the land in the eastern area of Dairi District is land with hilly topographical conditions and dryland forests and shrubs still dominate its land cover. Silahisabungan Sub-district is advanced in agriculture and fisheries. It was recorded that the productivity of onions and freshwater fisheries reached 2,392 tons and 295 tons, respectively, in 2017 (Statistics Indonesia of Dairi District 2018). The survey results in the field showed that the practice of clearing land by burning 
often leads to uncontrolled forest and land fires due to community negligence. The fire that spread up the hill was very difficult to extinguish, so it was not uncommon for forest and land fires to only be extinguished as much as possible, not completely.

\section{The relationship of the hotspot density with variables constructing the fire vulnerability level model}

The actual score in the composite mapping analysis shows the conditions of fire activity in an area (Thoha et al. 2017). The estimated score generated from the regression equation between the land cover class and the actual score follows a polynomial pattern (order 2) with a determination coefficient $\left(\mathrm{R}^{2}\right)$ of $69 \%$ (Figure 2 ). The pattern in Figure 2 shows that the more land cover leads to less dense vegetation (shrubs, dryland farming, open land), the estimated score is getting higher. This is presumably due to the large number of burning fields that were deliberately carried out by the community. In the event of a long dry season, this type of shrubland cover can generally provide dry and flammable fuel. Sumardi and Widyastuti (2004) stated that for every fire process, the factors of fuel, oxygen (air) and heat are prerequisites that must exist in the proper conditions and comparisons.

The estimated score generated from the regression equation between the actual score and the distance from the road follows an exponential pattern with a determination coefficient $\left(\mathrm{R}^{2}\right)$ of $85 \%$ (Figure 3 ). This pattern shows that the farther from the road, the higher the estimated score. The highest score was located at the location farthest from the road (3,500 meters). This is because the river network is usually used as community access to carry out various activities, particularly cultivating land near rivers, which are generally easy to manage and monitor and near water sources. The fire incidents are far from the river even in locations where there is no human activity at all, such locations are far from water sources and are difficult to extinguish. Fires occurring nearby rivers have the advantage of being controlled and extinguished in time with the river water itself. According to Rochgiyanti (2011), humans always need water to meet their daily needs, so rivers play an important role for people who live in forests and along the rivers.

The estimated score generated from the regression equation between the actual score and the distance from the road follows an exponential pattern with a determination coefficient $\left(\mathrm{R}^{2}\right)$ of $52 \%$ (Figure 4$)$. This pattern shows that the farther the road is, the higher the estimated score. The highest score was located farthest from the road $(11,500$ meters). In fact, road access will encourage someone to cultivate or open new land because roads make access easy to agricultural/plantation locations. However, the groundtruthing results showed that the fire occurred at a hilly location far from the road network. This was predictable because the land close to the road has been managed a lot, thus in the following year, people will open new land in a location that is far from the road. Another possibility why many fires occur far from the road is that burning land is no longer allowed by the government, but many people carry it on because of the lower costs.

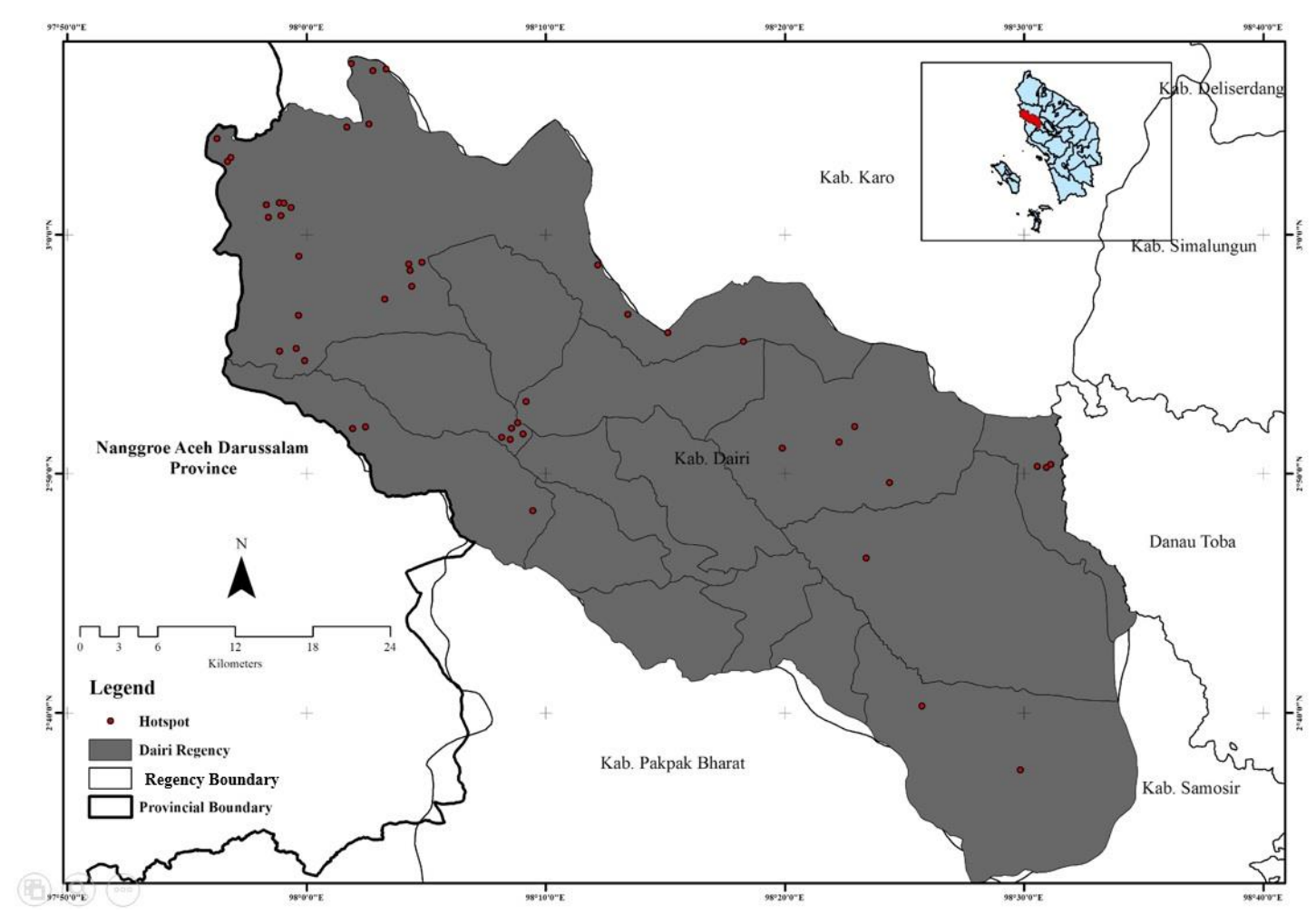

Figure 1. Map of the hotspot distribution in 2016 in Dairi District, North Sumatra Province, Indonesia 


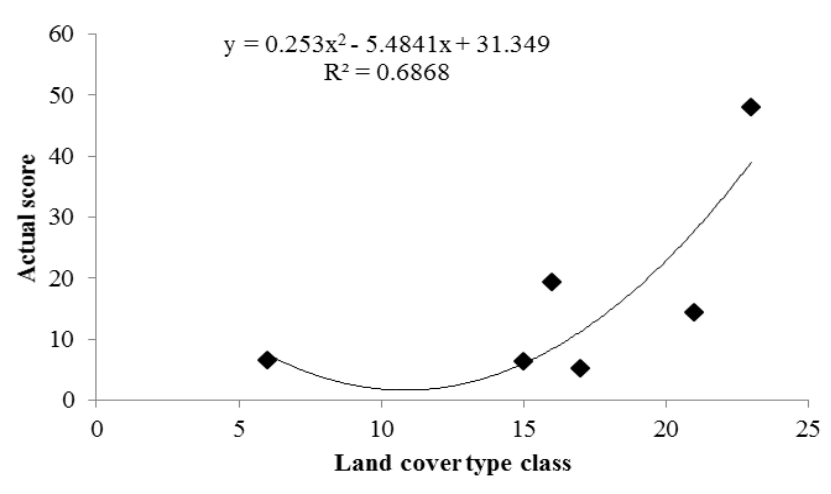

Figure 2. The relationship between fire activity (actual score) and land cover. Notes: Secondary dryland forest (6), Dryland farming (15), Plantation forest (16), Paddy field (17), Shrub (21) and Open land (23)

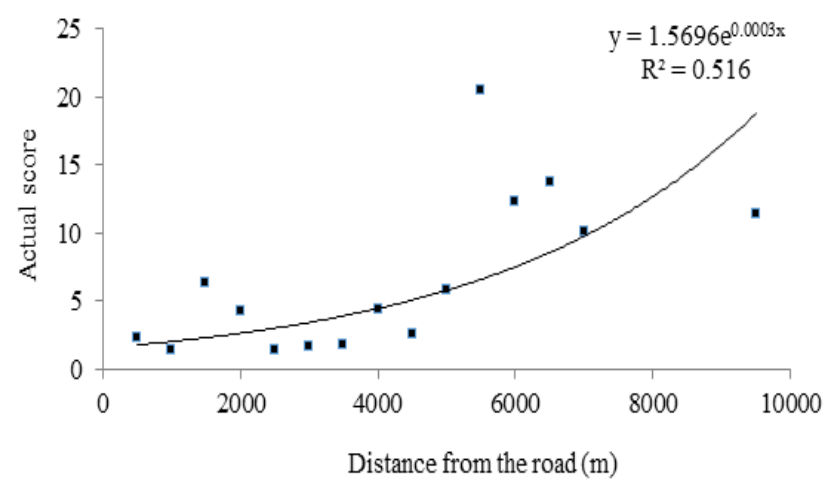

Figure 4. The relationship between actual score and distance from the road

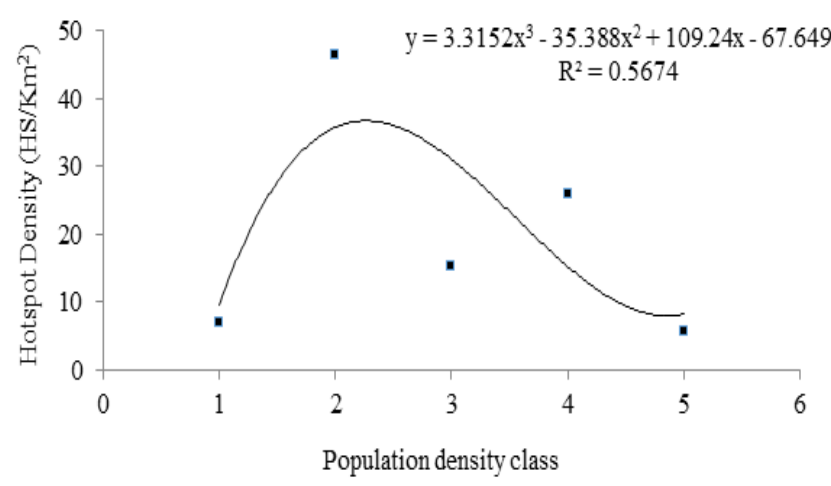

Figure 6. The relationship between actual score and population density

The estimated score generated from the regression equation between the actual score and the distance from the road follows a polynomial pattern (order 2) with a determination coefficient $\left(\mathrm{R}^{2}\right)$ of $73 \%$ (Figure 5). This pattern shows that the farthest from the settlement, the higher the estimated score. The highest score was in the location farthest from the settlement (10,000 meters). In practice, people tend to open and burn land that is not far from the settlement so that the monitoring and land management activities are easier.

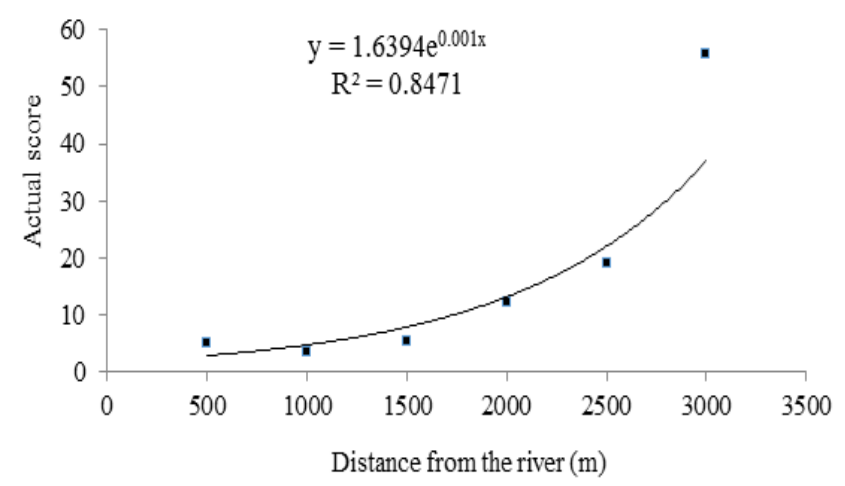

Figure 3. The relationship between fire activity and distance from the river

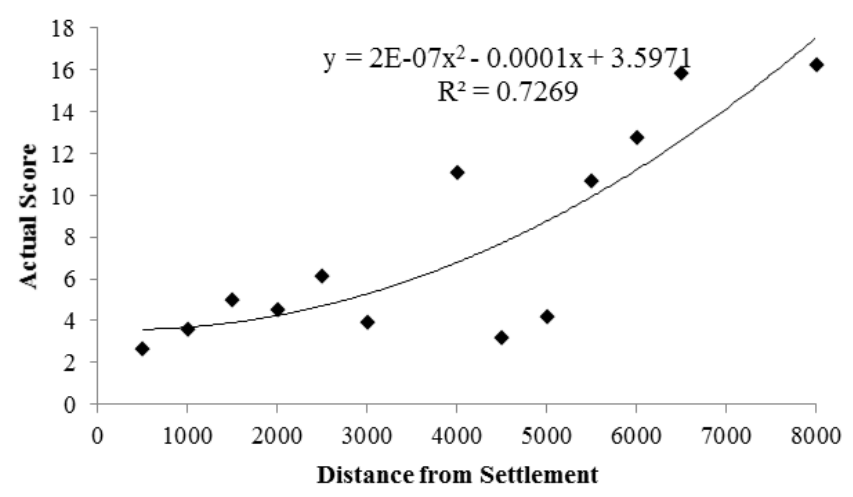

Figure 5. The relationship between actual score and distance from the settlement

The estimated score generated from the regression equation between population density and the actual score follows a polynomial pattern (order 3 ) with a determination coefficient $\left(\mathrm{R}^{2}\right)$ of $57 \%$ (Figure 6 ). This pattern shows that the higher the population density, the lower the actual score or fire activity (Figure 6). The highest score was found in locations with low population density. Areas with highdensity levels are generally settlement land or village centers. In practice, the community tends to open and burn land at some distant location from the village center because it avoids the spread of fire to the village center or owned land and avoids smoke that can interfere with community activities. Lands with a high actual score or that are vulnerable to the fire were in locations with a lowdensity level, generally found on lands far from the village and far from monitoring burning activities.

The spatial model of forest and land fire vulnerability level

The Forest and Land Fire Vulnerability Level Model is a regression model with variables that have a significant effect. Through linear regression analysis of the five variables (land cover, distance from the road, distance from the river, distance from the settlement and population density) to estimate hotspot density, the coefficients and variable weights were obtained from the model construction regression equation shown in Table 2. 
Based on the determined weights (Table 2) determined, the equation for obtaining the Composite Score of Forest and Land Fire Vulnerability Level is:

$Y=0.022 X_{1}+0.214 X_{2}+0.113 X_{3}+0.482 X_{4}+0.169 X_{5}$

Where,

Y : Composite Score

$\mathrm{X}_{1}$ : rescaled score of land cover

$\mathrm{X}_{2}$ : rescaled score of distance from the road

$\mathrm{X}_{3}$ : rescaled score of distance from the river

$\mathrm{X}_{4}$ : rescaled score of distance from the settlement

$\mathrm{X}_{5}$ : rescaled score of population density

The highest to lowest weights of the five variables constructing the forest and land fires of the forest and land fire vulnerability level model was the distance from the settlement $(48.2 \%)$, distance from the road $(21.4 \%)$, population density (16.9\%), distance from the river $(11.3 \%)$ and land cover $(2.2 \%)$. The biophysical factor (land cover) had a lower weight, while the human activity factors (distance from the settlement, distance from the road, distance from the river, and population density) had a relatively high weight. The spatial modeling of the above equation produced a map of the forest and land fire vulnerability level as presented in Figure 7. The distribution of the area and the percentage of the area of each forest and land fire vulnerability level is presented in Table 3.
Based on the calculation of the area, it was found that most of the Dairi District area was covered by areas with a very low fire vulnerability level. The high and very high vulnerability classes were indicated by the orange and red colors that were scattered in Silahisabungan and Tanah Pinem Sub-districts.

Table 2. Composite Score Coefficients and Weights of the Forest and Land Fire Vulnerability Level Model in Dairi District, North Sumatra Province, Indonesia

\begin{tabular}{lcc}
\hline Variable & Coefficient & Weight \\
\hline Land Cover & 0.000015 & 0.022 \\
Distance from the Road & 0.000146 & 0.214 \\
Distance from the River & 0.000077 & 0.113 \\
Distance from the Settlement & 0.000329 & 0.482 \\
Population density & 0.000115 & 0.169 \\
\hline
\end{tabular}

Table 3. Distribution of vulnerability area with five classes of the forest and land fire vulnerability level model in Dairi District, North Sumatra Province, Indonesia

\begin{tabular}{lcll}
\hline $\begin{array}{l}\text { Vulnerability } \\
\text { level }\end{array}$ & $\begin{array}{c}\text { Model } \\
\text { composite } \\
\text { score }\end{array}$ & Area (ha) & $\begin{array}{c}\text { Percentage } \\
(\%)\end{array}$ \\
\hline Very Low & $10.313-16.788$ & $2,479,718.51$ & 48.58 \\
Low & $16.789-25.433$ & $1,694,950.16$ & 33.20 \\
Medium & $25.434-28.352$ & $768,052.48$ & 15.05 \\
High & $28.353-33.319$ & $129,398.48$ & 2.53 \\
Very High & $33.320-78.281$ & $32,545.05$ & 0.64 \\
\hline
\end{tabular}

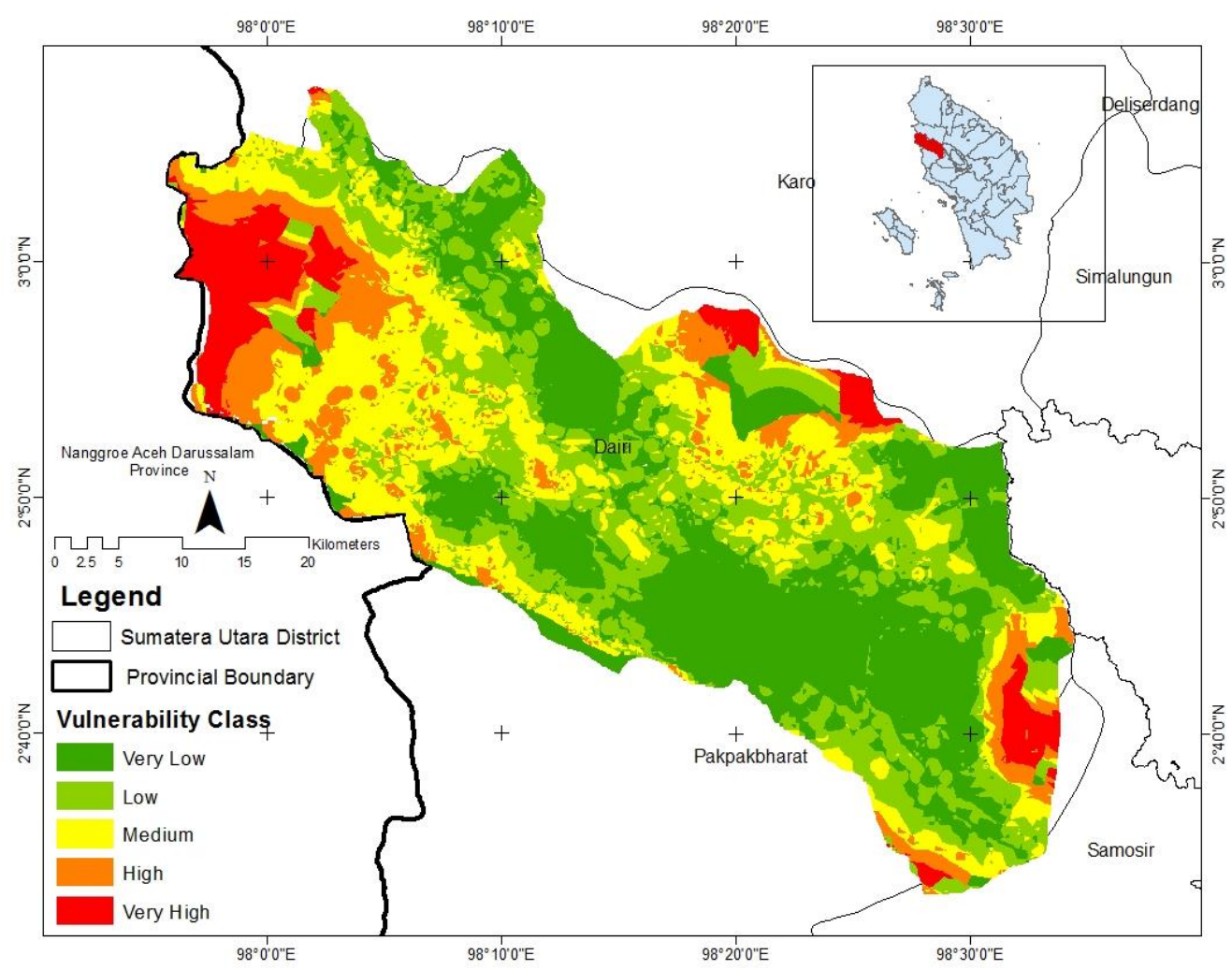

Figure 7. Map of the forest and land fire vulnerability level in Dairi District, North Sumatra Province, Indonesia 


\section{Discussion}

The hotspots in the Dairi District area were related to the peak of the dry season. The hotspots related to community activities were detected during the dry season, including June-August. Syaufina and Hafni (2018) stated that climate is one of the natural factors that can cause forest and land fires because climatic conditions can affect the level of surface fuel dryness, the amount of oxygen available and the speed at which the fire spreads. A study by Tata et al. (2018) in Riau Province found a similar pattern that hotspots increased in number from June to August.

Areas that were included in the high and very high vulnerability class of forest and land fire were generally not the areas with good forest canopy cover. These areas were generally dryland farming, secondary dryland forest, shrubs, plantation forest and open land. It may be because these types of land cover provide combustible fuel during the dry season. A previous study by Thoha et al. (2019) stated that human activity factors have a role in determining the forest and land fire vulnerability level in North Sumatra Province, contributing more than $60 \%$ of the spatial model. The study also found that shrubs and grasslands were the types of land cover that were almost the starting sources of the fires in North Sumatra Province.

Based on the results of the ground-truthing, the type of land cover that often burns belonged to non-forest areas that were open to access and were not maintained. Unmaintained land was often the source of start of fires and these type of land areas were located far from roads, rivers and settlements, as a result of which there were less monitoring of various activities. This is consistent with the spatial model which found that distance from the road, population density and distance from the river were the dominant variables in determining the forest and land fire vulnerability level in Dairi District.

Based on filed survey, some burnt areas were found in land clearing activities area for planting corn and other agricultural commodities. Some of the other burnt lands were found on abandoned land where fire incidences occur every year in hilly landscapes. These areas were difficult to access by the firefighting team. The burnt areas were found in Tanah Pinem and Silahisabungan Sub-districts that mostly in the form of shrubs and grassland. It is suspected that the fire start from the community's uncontrolled clearing of land and then spread to the unmaintained land.

Thoha et al. (2017) and Thoha and Ahmad (2018) stated that the cause of fires comes from activities on unmaintained lands. Shrubs is land cover type that has frequently detected fire activities based on study by Thoha et al. (2020). The same study in Jambi also explained that there was a strong relationship between non-forested land in the form of shrubs and swampy scrub which were cleared for conversion to plantations (Prasetyo et al. 2016). The study in Riau Province also found a pattern that burned land was mostly related to forest loss where non-forest land became burned areas year after year (Andrianto et al. 2019)

In conclusion, the variable that played the most role in the forest and land fire vulnerability level model in Dairi
District was the distance from the settlement. This study also found that open land, the farthest distance to the road, the farthest distance to the river, the farthest distance to the settlement and the densest population were the driving factors for increased fire activity. The spatial model of the vulnerability level to forest and land fires in Dairi District was $\mathrm{Y}=0.022 \mathrm{X}_{1}+0.214 \mathrm{X}_{2}+0.113 \mathrm{X}_{3}+0.482 \mathrm{X}_{4}+$ $0.169 \mathrm{X}_{5}$. Land cover having high-very high vulnerability level belonged to open land dominated by grass. The largest areas with a high-very high forest fire vulnerability level in Dairi District were spread over Tanah Pinem and Silahisabungan Sub-districts.

\section{ACKNOWLEDGEMENTS}

This study was funded by the TALENTA Fund of Universitas Sumatra Utara for the Fiscal Year of 2019 with Contract Number 272/UN5.2.3.1/PPM/KP-TALENTA USU/2019. We also thank the Disaster Management Agency of the Dairi District of North Sumatra Province and the field team supporting data collection. We also give our highest appreciation to the editor and reviewers team who have provided their corrections and comments.

\section{REFERENCES}

Andrianto HA, Spracklen DV, Arnold SR. 2019. Relationship between fire and forest cover loss in Riau Province, Indonesia between 2001 and 2012. Forest 10: 889. DOI: 10.3390/f10100889.

BPS [Biro Pusat Statistik]. 2018. Kabupaten Dairi dalam Angka. Biro Pusat Statistik Sumatera Utara, Medan. [Indonesian]

BNPB [Badan Penanggulangan Bencana Nasional]. 2016. Risiko Bencana Indonesia. Direktur Pengurangan Risiko Bencana BNPB, Jakarta. [Indonesian]

Ceccato P, Jaya INS, Qian JH, Tippett MK, Robertson AW, Someshwar S. 2010. Early Warning and Response to Fires in Kalimantan, Indonesia. IRI Technical Report 10-14, International Research Institute for Climate and Society, Palisades, NY.

Crippa P, Castruccio S, Archer-Nicholls S, Lebron GB, Kuwata M, Thota A, et al. 2016. Population exposure to hazardous air quality due to the 2015 fires in Equatorial Asia. Sci Rep 6: 37074. DOI: $10.1038 /$ srep37074.

Goldammer JG, Brady M, Csiszar IA, de Groot WJ, Justice CO, Keenan T, et al. 2006. Development of a Global Wildland Fire Early Warning System within the envisaged Multi-Hazard Global Early Warning System. Presentation Paper, Third International Early Warning Conference Scientific and Technical Symposium. Bonn, Germany, 28 March 2006.

Huijnen V, Wooster MJ, Kaiser JW, Gaveau DLA, Flemming J, Parrington M, et al. 2016. Fire carbon emissions over maritime Southeast Asia in 2015 largest since 1997. Sci Rep 6: 26886. DOI: $10.1038 /$ srep26886.

Jaya INS, Boer R, Samsuri. 2007. Developing Fire Risk Index in Central Kalimantan. International Research Institute and Bogor Agricultural University, Bogor.

Kiely L, Spracklen DV, Wiedinmyer C, Conibear L, Reddington CL, Archer-Nicholls S. 2019. New estimate of particulate emissions from Indonesian peat fires in 2015. Atmos Chem Phys 19: 11105-11121. DOI: 10.5194/acp-19-11105-2019.

Koplitz SN, Mickley LJ, Marlier ME, Buonocore JJ, Kim PS, Liu T, et al. 2016. Public health impacts of the severe haze in Equatorial Asia in September-October 2015: Demonstration of a new framework for informing fire management strategies to reduce downwind smoke exposure. Environ Res Lett 11: 94023. DOI: 10.1088/17489326/11/9/094023. 
Prasetyo LB, Dharmawan AH, Nasdian FT, Ramdhoni S. 2016. Historical forest fire occurrence analysis in Jambi Province during the period of 2000-2015: Its distribution \& land cover trajectories. Proc Environ Sci 33: 450-459. DOI: 10.1016/j.proenv.2016.03.096.

Reddington CL, Yoshioka M, Balasubramanian R, Ridley D, Toh YY, Arnold S, Spracklen DV. 2014. Contribution of vegetation and peat fires to particulate air pollution in Southeast Asia. Environ Res Lett 9: 094006. DOI: 10.1088/1748-9326/9/9/094006.

Rochgiyanti. 2011. Fungsi Sungai Bagi Masyarakat di Tepian Sungai Kuin Kota Banjarmasin. J Komunitas 3 (1): 51-59. DOI 10.15294/komunitas.v3i1.2293.

Sumardi, Widyastuti SM. 2004. Dasar-Dasar Perlindungan Hutan. Gadjah mada University Press, Yogyakarta. [Indonesian]

Syaufina L, Hafni DAF. 2018. Variability of Climate and Forest and Peat Fires Occurrences in Bengkalis District, Riau. J Silvikultur Tropka. 9 (1): 60-68. [Indonesian]

Tata HL, Narendra BH, Mawazin. 2018. Forest and land fires in Pelalawan District, Riau, Indonesia: Drivers, pressures, impacts and responses. Biodiversitas 19 (2): 544-551. DOI: 10.13057/biodiv/d190224.

Thoha AS, Saharjo BH, Boer R, Ardiansyah M. 2014. Spatiotemporal distribution of peatland fires in Kapuas District, Central Kalimantan
Province, Indonesia. Agric For Fish 3 (3): 163-170. DOI: 10.11648/j.aff.20140303.14.

Thoha AS, Saharjo BH, Boer R, Ardiansyah M. 2017. Forest and land fires hazard level modeling: case study of Kapuas, Central Kalimantan. In: Djalante R, Garschagen M, Thomalla F, Shaw R. (eds.) Disaster Risk Reduction in Indonesia. Disaster Risk Reduction (Methods, Approaches, and Practices). Springer, Cham. DOI: 10.1007/978-3-319-54466-3_22.

Thoha AS, Ahmad AG. 2018. Modeling of forest and land fires vulnerability level in North Sumatra Province, Indonesia. Environ Asia 11 (3): 1-14. DOI: 10.14456/ea.2018.34.

Thoha AS, Saharjo BH, Boer R, Ardiansyah M. 2019. Characteristics and causes of forest and land fires in Kapuas District, Central Kalimantan Province, Indonesia. Biodiversitas 20 (1): 110-117. DOI: 10.13057/biodiv/d200113.

Thoha AS, Sofyan M, Ahmad AG. 2020 Spatio-temporal distribution of forest and land fires in Labuhanbatu Utara District, North Sumatra Province, Indonesia. IOP Conf Ser Earth Environ Sci 454 (1): 012081. DOI: 10.1088/1755-1315/454/1/012081.

World Bank. 2015. Indonesia Economic Quarterly: Reforming Amid Uncertainty. World Bank, Jakarta, Indonesia. 